\title{
CAREER GROWTH AND DEVELOPMENT: ROLE OF CONTINUING EDUCATION AMONG TEACHERS
}

\author{
Priyanka Bhaskar \\ Doon Business School, Dehradun, Uttarakhand, India \\ bhaskar.priyanka06@gmail.com \\ Padmalosani Dayalan \\ University of Technology and Applied Sciences, Ibra, Oman \\ d.padmalosani@gmail.com
}

\begin{abstract}
This paper aims to highlight the role of continuing education among the teachers of India. The study identifies factors which influence teachers in Higher education institutions (HEI) for continuing education. The paper also explores the impact of continuing education on career growth and development. A systematic survey was conducted among the teachers in Higher education institutions of Uttarakhand, India. Factor analysis is used to identify the important factors that influence teachers to enrol for continuing education. SPSS and AMOS are used to analyse the data. The findings of the study indicate that factors like time, financial support, job opportunities, knowledge, skills, and abilities play a detrimental role among teachers for continuing education. This study also reveals that continuing education has a positive impact on career growth and development of teachers. Continuing education helps the teachers to explore better career opportunities, provides job security, salary increment, and promotion which contributes to their professional growth and personality development. Continuing education in teachers demonstrates a significant role in the development of interpersonal skills, technical skills and inculcates self-confidence that contributes to their personal growth. The importance of paper increases amidst the COVID19 pandemic and the launch of the National Education Policy in India, as the paper will provide support to the Higher education institutes and Government to frame policies and strategies to imbibe continuing education as an integral part of the education system. The paper by enumerating its benefits, motivates the teachers to enhance their qualifications and enhance their future prospects.
\end{abstract}

Keywords: Continuing Education, Career Development, Professional Growth, Personal Growth, Education Sector, Teachers, Faculty.

\section{INTRODUCTION}

A University Office circular reads "It is mandatory for every faculty member to get two certificates of short term courses during each semester or else their appraisal may be adversely affected". This is one of the many office circulars which focuses on continuing education for teachers in India. Continuing Education is 
an integral part of every industry, as it makes the employee and organization compete, excel, and move towards the zenith of success in the respective field. Various industries adopt different methods to enhance the skills of their employees by doing international tie-ups, motivating them to acquire online certification courses. The education sector is the most dynamic sector which requires continuous upgradation of teachers so that they are able to enhance the standard of education and at the same time provide growth to the education institution and the country. Many teachers don't continue with their education once they enter into the job, the teachers during their tenure become obsolete in terms of knowledge and skills with the ever-evolving education sector demands. To be effective in rendering knowledge and demonstrate an influential role in the development of students, it is but imperative that the teachers have to remain astounding in the dynamic environment. Continuing education consists of programs to facilitate teachers with new ways of imparting education and imbibe new skills. Considered within the ambit of persisting learning, continuing education befit an addendum of the inceptive education. The Indian education system demands certain prerequisites to become a teacher if one wants to join primary teaching then Nursery teaching training certificate is mandatory, middle and senior school teachers require a Master's degree in the relevant subject along with a degree in Bachelors of Education. Accordingly, to teach in higher education institutes a degree in doctorate is essential. It is ascertained that Qualifications will make a person capable enough to impart knowledge to a particular group. However, doubt persist that since education is very dynamic then how a person who was awarded a degree in the year 2000 will be able to do justice to the subject in 2020. The education system in India has changed over the years; from Gurukul system to ICT enabled learning. With the changing environment, the education system also has changed at a greater pace than before. So the role of a teacher has also extended multifolded, they are no longer constrained to the subject of their specialization. The improvisation and modification of pedagogy is the main element to enhance learners' performance. Various government agencies like University Grant Commission, department of higher education, department, and literacy national council for teacher education advocate lifelong learning for teachers to maintain the standards of education. Many programs have been initiated by the education department in India like massive open online courses, national program on technology-enhanced learning etc.to enhance the continuing education among the teachers of Higher education institutes. UGC has asked the institutions to get themselves accredited by the National Assessment and Accreditation Council (NAAC) with a minimum score of 2.5 by 2022. An important criterion to get accredited is the continuing education of teachers. So the Ministry of Higher education in India realizes the importance of lifelong learning for teachers for which they are offering many programs at a minimal fee and at the same time making it mandatory. Continuing education is a direct pathway to progression, providing teachers with a competitive edge to attain a 
rewarding career. Continuing education approach designed to train teachers for dealing with the emerging trends and demands of teaching with new skills (Garuba, 2004).

This paper aims to highlight the role of continuing education among the teachers of India. The study identifies factors which influence teachers in Higher education institutions (HEI) for continuing education. The paper also explores the impact of continuing education on career growth and development

\section{LITERATURE REVIEW}

\subsection{Importance of continuing education among employees}

Every employee in any organization requires to be updated about the recent trend that is being followed in their discipline. Continuing education helps employees to become more proficient in their current position and provides them an improved chance of getting a promotion, acquire additional skills, and attain knowledge benefits (Chopra et al., 2021, Chaudhary and Bhaskar, 2016; Gupta et al., 2015). Continuing education plays an important role in higher education institutions. Proficient and updated teachers support the educational higher education institutions to achieve their mission and vision. Continuing education boosts the confidence of the teachers and also helps in the growth of the institutions and promoting quality teaching and learning (Ravhuhali, et al., 2015). Continuing education enhances self-development both professionally as well as personally. Teachers get recognized and their competency increases. With higher degrees, certification, and knowledge their opportunities and bargaining power increases for better Job opportunities. Majority of the studies are done on Nursing (Shinners, and Graebe, 2020, Mohamadi, et al., 2019 , Jackson, et al., 2019 , Chung, et al., 2019 , Tømte, 2019 ,Vaganova, et al., 2019 , Curran, et al., 2019, Cox and Grus 2019, Nagovitsyn, et al., 2019 , Özer, et al., 2019 , Zuchowski, et al., 2017); business process outsourcing (Priya, K., et al., 2015); Health care system (Grus and Rozensky, 2019, Alturkistani, et al., 2018, Zuchowski, et al., 2017, Sockalingam, et al., 2016, De Souza Duarte, et al., 2016); Education ( Adu and Okeke, 2014; Wan, et al., 2010; Raza, 2010; Jafri, 2009; Bullough, 2009; Lawton, and Wimpenny, 2003); Medical Education (Azra, 2020, McGowan, et al., 2020, Breunig, et al., 2020, Grammatikopoulou, et al., 2019, Devries, et al., 2019); Engineering (Bullock, et al., 2020;PérezFoguet and Lazzarini 2019; Hoffenson, et al., 2019); Accounting and Auditing (Reinstein, et al., 2019). Available literature suggests that limited study is conducted in the role of continuing education for the teachers. No study was conducted to analyze how continuing education plays an imperative role in the career growth and development of teachers teaching in higher education. This study focuses on the role of continuing education among teachers and its impact on their career growth and development.

\subsection{Factors influencing continuing education}

Teaching is dynamic and learning is not absolute but exponential. It is evident that teachers have to upgrade themselves with respect to the ongoing developments. There is always a need for teachers to 
'brush' up their knowledge and skills. They are required to be in touch with innovative developments in the industry and train students accordingly. Many teachers still don't opt for continuing education due to several reasons. Garuba, (2004) adduced the reasons for non-participation among teachers which includes financial difficulties, lack of information on the continuing education programs, and unawareness of the potential benefit on professional output. Teachers need to be self-motivated for learning, external motivation from the institutions and their education level also predict level in professional development among teachers (Livneh and Livneh 1999). Teacher's personal factors, task factors, and their work environment factors also influence participation in professional learning activities (Kwakman, 2003)

Teachers don't want to invest additional money in getting additional qualifications or certification. They lack financial support from the employer for continuing education to upgrade their knowledge and skills (McKay and Sappa, 2019; Joshi et al., 2020; Gupta \& Bhaskar, 2021, Joshi and Bhaskar, 2021; Bhaskar et al., 2021). According to Bayar (2013), teachers' attitudes towards professional development is influenced by time and funding. Continuing education demand time for completing courses or certification. Due to a lack of time and workload, many teachers don't enroll in any continuing education program. (Özer, et al., 2019; Gupta \& Bhaskar, P. 2020). Continuing education offers better job opportunities, some research emphasize that teachers want to enroll only in those programs which can offer better employment opportunities (Curran, et al., 2019; Cox, and Grus, 2019). Continuing education enhances productivity and creativity of the employees, they learn and imbibe new skills that are in demand at the workplace thus they are able to expand their job opportunities (Laal, et al., 2014; Varricchio, 1998). A teacher wishes to enroll in continuing education to increase the knowledge, skills, and abilities of the teachers (Nagovitsyn, et al., 2019). Continuing education inculcates the right skills, attitudes, and understanding which not only makes them better employees but they have also developed them as better individuals. Continuing education results in enhanced knowledge and skills, staff satisfaction and retention (Laal, et al., 2014). Table 1 shows the Factor influencing teachers for continuing education

TABLE 1: FACTOR INFLUENCING TEACHERS FOR CONTINUING EDUCATION

\begin{tabular}{|l|l|}
\hline Factors & Reference \\
\hline Financial support & $\begin{array}{l}\text { Tømte, 2019; Vaganova, et al., 2019; McKay and Sappa, 2019; Neagu, 2014; } \\
\text { Daniels, et al., 2002; Chaudhary, \& Bhaskar, 2016; Bhaskar et al., 2021 }\end{array}$ \\
\hline Time & $\begin{array}{l}\text { Oliver, 2019; McKay and Sappa, 2019; Özer, et al., 2019; Adu and Okeke, 2014; } \\
\text { Stolee, et. al., 2005; Joshi et al., 2020; Bhaskar et al., 2021 }\end{array}$ \\
\hline Job opportunities & Curran, et al., 2019; Cox and Grus, 2019; Bhaskar et al., 2021 \\
\hline $\begin{array}{l}\text { Knowledge, skills } \\
\text { and abilities }\end{array}$ & $\begin{array}{l}\text { Nagovitsyn, et al., 2019; Curran, et al., 2019; Cox and Grus; } 2019 \text {; Özer, et al., } \\
\text { 2019; Bhaskar et al., 2021 }\end{array}$ \\
\hline
\end{tabular}

\subsection{Career growth and development}

Continuing education develops the teachers professionally and generates self-efficacy, due to which they will be able to generate relevant and personalized courses for students. They are 
able to implement new delivery methods and are exposed to new assessment styles and data maintenance strategies. Grangeat and Gray (2007) studied the effect of continuing professional development programs on teachers' learning. Continuing education enhances knowledge and personality of the teachers thus it enables them to explore more avenues for better career growth and development. Continuing education increases probability of promotion, salary increment, ability to make a career transition, Improves image and marketability, Improves their lifestyle and Increases personal development. Previous research shows that continuing education has a positive impact on career growth and development (Bentley, 2019; Tsoi, et al., 2018). Continuing education helps in better job opportunities, job security, salary hike and promotion (Myalkina, et al., 2018; Nikonova, et al.,2019; Bulaeva et al., 2018; Kamenez et al., 2019; Nagovitsyn, et al., 2019; Curran, et al., 2019; Cox and Gurus 2019). Learning is a lifelong process and investing time in continuing education results in personal growth which helps in the development of interpersonal skills, technical skills and boosts self-confidence (Özer, et al., 2019; Sharma and Poudel, 2018; Tsoi, et al., 2018; Bindon, 2017; Neimeyer, et al., 2017).

\section{CONCEPTUAL FRAMEWORK}

The proposed conceptual framework of the study is showed in the figure. 1. Section 1 comprised of factors influencing continuing education and section 2 consists of dimensions of career growth and development. Factors influencing continuing education are financial and time support Job opportunities, knowledge, skills, and abilities. Career growth and development dimensions include personal growth and professional growth.

FIGURE 1: CONCEPTUAL FRAMEWORK PROPOSED IN THE STUDY

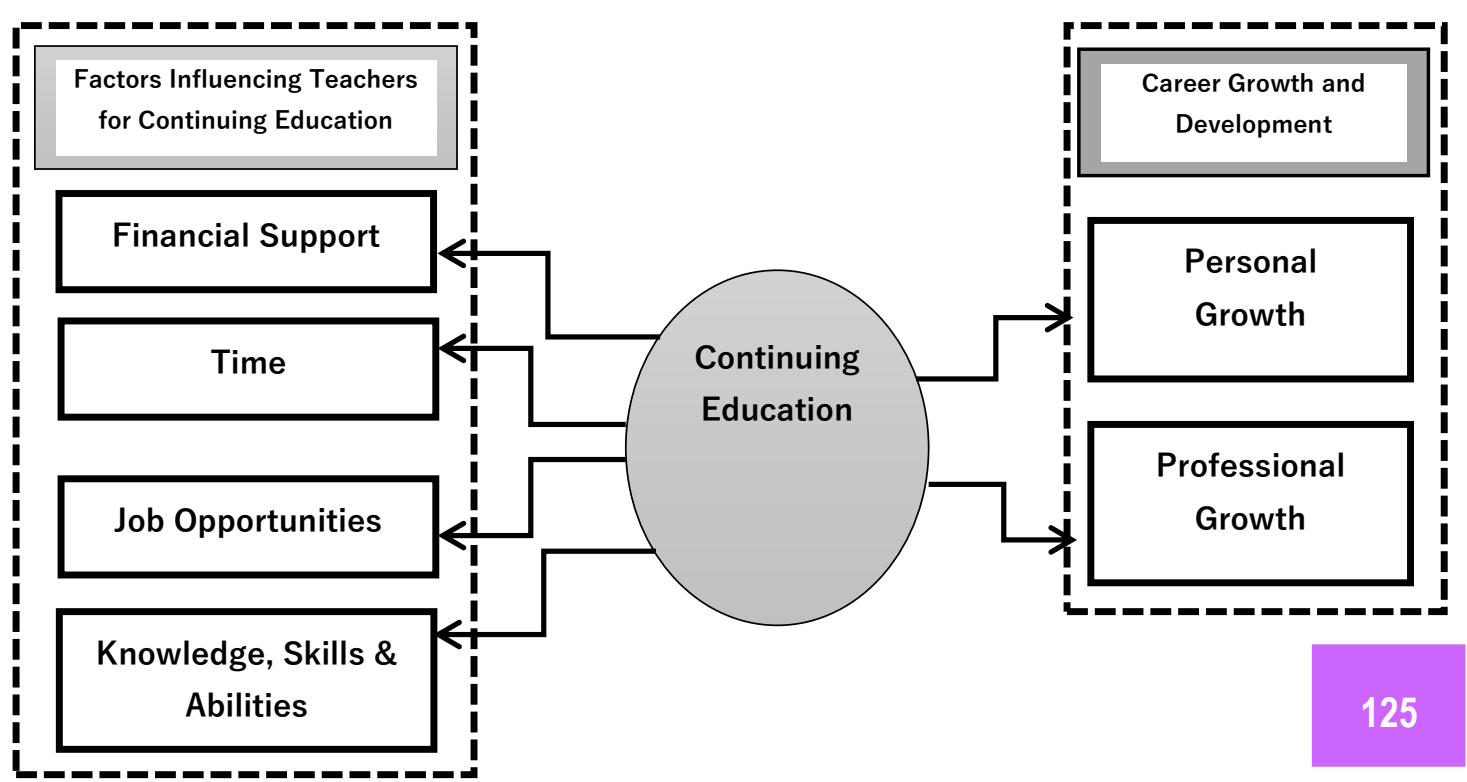




\section{RESEARCH METHODOLOGY}

The study identifies the factors which influence teacher for continuing education and its impact on their career growth and development of teachers in Higher Education Institutions (HEls) of Uttarakhand, India. A systematic survey of 900 teachers was conducted in the HEls through structured questionnaires. The questionnaire was divided in two sections. Section 1 included factors influencing continuing education and section 2 included the dimensions of career growth and development. Factors influencing the teachers to opt for continuing education were job opportunities, knowledge, skills, abilities, time, and financial support. Career growth and development dimensions are personal growth and professional growth. The items were measured on a five-point Likert scale. The questionnaire items were identified on the basis of literature review to ensure content validity and was also pilot tested among the teachers. 5 questions were removed and 7 questions were reframed after the pilot testing. After making the necessary changes, it was again tested on different sets of teachers. Out of 900 teachers, only 350 teachers responded to the questionnaire. 35 responses were discarded because some questions were not answered. The data was collected from January 2021 to April 2021. Factor analysis is used to identify the factors of continuing education and career growth and development among the teachers. SPSS and AMOS is used for analysing the data. Table 2 shows indicates the reliability and validity of factor analysis for continuing education and career growth and development variables.

TABLE 2: RELIABILITY AND VALIDITY

\begin{tabular}{|l|l|l|}
\hline \multicolumn{3}{|c|}{ Reliability Statistics } \\
\hline Cronbach's Alpha & N of Items \\
\hline .803 & 26 \\
\hline \multicolumn{3}{|c|}{ KMO and Bartlett's Test } \\
\hline $\begin{array}{l}\text { Kaiser-Meyer-Olkin Measure of } \\
\text { Sampling Adequacy. }\end{array}$ & Approx. Chi-Square & 2883.938 \\
\cline { 2 - 4 } & $\mathrm{df}$ & 171 \\
\cline { 2 - 4 } & Sig. & .000 \\
\hline
\end{tabular}

\section{DATA ANALYSIS AND RESULTS}

An exploratory factor analysis (EFA) was done to find the correlating items in the first-order construct then second-order SEM was used to test the proposed conceptual framework. In this study two second-order model was developed; first is continuing education factors which constitute four first-order constructs (Job opportunities, knowledge, skills and abilities, time and financial support). The career growth and development include two first-order constructs (personal growth and professional growth.

\subsection{Factor analysis}

Table 3 exhibit the factor loadings of the items of continuing education and career growth and development. The factor loadings is above 0.5 that shows high correlation with the particular factors (Hair et al., 2016). The total 6 factors have been extracted from the principal component analysis. Five items 
Bhaskar, P., \& Dayalan, P.

CAREER GROWTH AND DEVELOPMENT: ROLE OF CONTINUING EDUCATION AMONG TEACHERS

have been clustered into Job opportunities, four items have been clustered into Knowledge, Skills, and abilities, four items have been clustered into financial support, five items have been grouped time in time requirements for completing the course, four items have been clustered into professional growth and four items have been clustered into professional.

\begin{tabular}{|c|c|c|c|c|c|c|c|}
\hline & & & & & ompon & & \\
\hline & & 1 & 2 & 3 & 4 & 5 & 6 \\
\hline \multirow{4}{*}{$\begin{array}{l}\text { Financial } \\
\text { support }\end{array}$} & Fl1 & 0.82 & & & & & \\
\hline & $\mathrm{Fl} 2$ & 0.83 & & & & & \\
\hline & $\mathrm{Fl} 3$ & 0.80 & & & & & \\
\hline & F14 & 0.83 & & & & & \\
\hline \multirow{5}{*}{$\begin{array}{l}\text { Time } \\
\text { requirements } \\
\text { for } \\
\text { completing }\end{array}$} & TR1 & & \begin{tabular}{|l} 
\\
\end{tabular} & & & & \\
\hline & TR2 & & \begin{tabular}{|l|}
0.83 \\
\end{tabular} & & & & \\
\hline & TR3 & & 0.85 & & & & \\
\hline & TR4 & & \begin{tabular}{|l|l|}
0.84 \\
\end{tabular} & & & & \\
\hline & TR5 & & \begin{tabular}{|l|l|}
0.85 \\
\end{tabular} & & & & \\
\hline \multirow{5}{*}{$\begin{array}{l}\text { Job } \\
\text { opportunities }\end{array}$} & E01 & & & 0.89 & & & \\
\hline & EO2 & & & 0.79 & & & \\
\hline & EO3 & & & 0.85 & & & \\
\hline & EO4 & & & 0.79 & & & \\
\hline & E05 & & & 0.82 & & & \\
\hline \multirow{4}{*}{$\begin{array}{l}\text { Knowledge, } \\
\text { Skills, and } \\
\text { abilities }\end{array}$} & ANK1 & & & & 0.85 & & \\
\hline & ANK2 & & & & 0.81 & & \\
\hline & ANK3 & & & & 0.85 & & \\
\hline & ANK4 & & & & 0.90 & & \\
\hline \multirow{4}{*}{$\begin{array}{l}\text { Professional } \\
\text { growth }\end{array}$} & FG1 & & & & & 0.70 & \\
\hline & FG1 & & & & & 0.81 & \\
\hline & FG3 & & & & & 0.78 & \\
\hline & FG4 & & & & & 0.81 & \\
\hline \multirow{5}{*}{$\begin{array}{l}\text { Personal } \\
\text { growth }\end{array}$} & SG1 & & & & & & 0.88 \\
\hline & SG2 & & & & & & 0.92 \\
\hline & SG3 & & & & & & 0.92 \\
\hline & SG4 & & & & & & 0.86 \\
\hline & \multicolumn{7}{|c|}{$\begin{array}{l}\text { Extraction Method: Principal Component Analysis. } \\
\text { Rotation Method: Varimax with Kaiser Normalization }\end{array}$} \\
\hline
\end{tabular}

\subsection{Structural equation model (SEM) approach}

Figure 2 illustrates the results of a SEM. The hypothesis is supported $(\beta=0.51, p<.000)$ by showing significant impact of continuing education on career growth and development. The Model fit indices a satisfactory fit between the hypothesized model and the observed data (Byrne 2010). The CFI of the model is .948 (close to .95) and RMSEA is.066 (less than .08) so this model is acceptable with the acceptable fit indices. 


\section{FIGURE 2: STRUCTURAL EQUATION MODEL (SEM)}

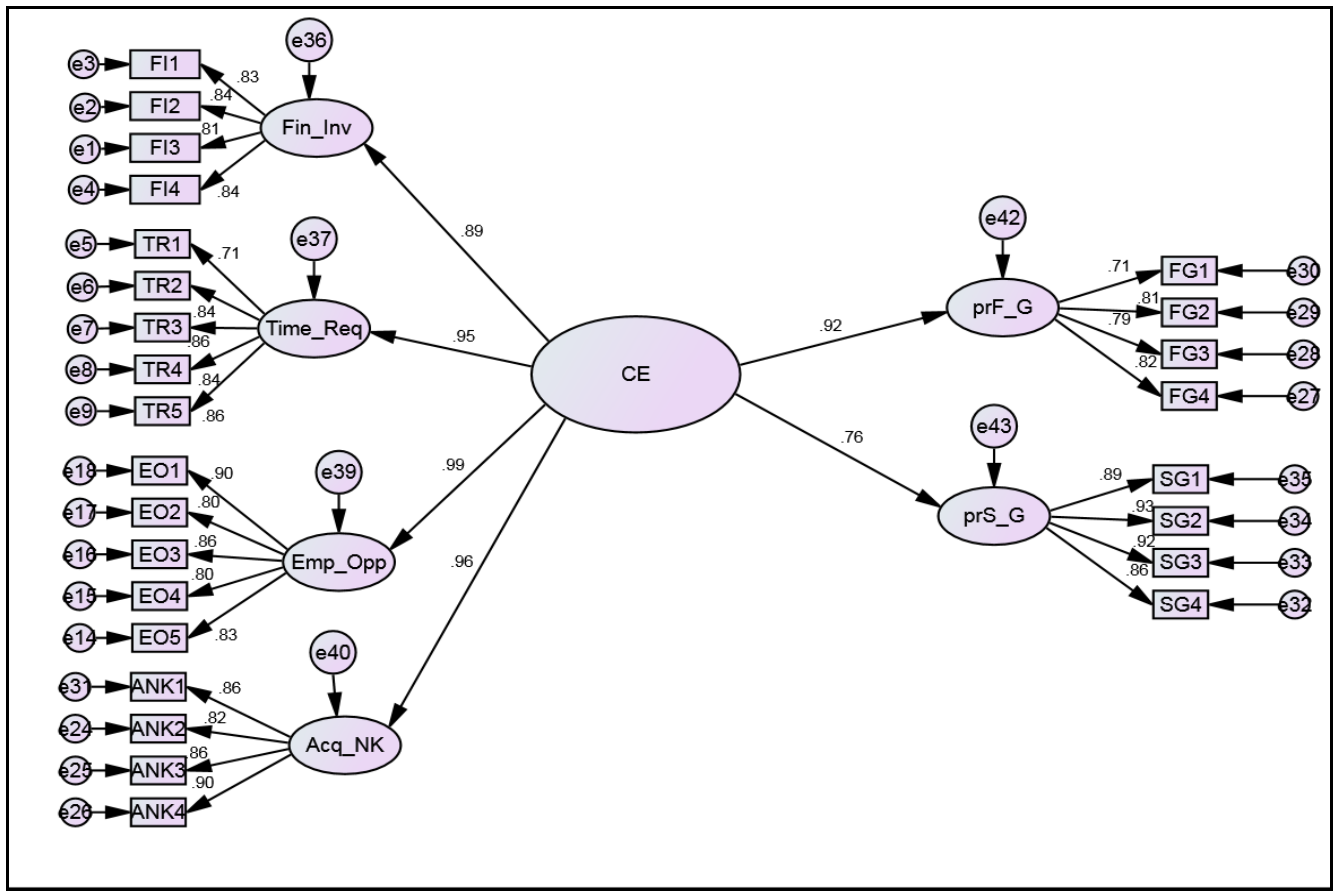

\section{FINDINGS}

The findings of the study indicate that factors like financial support, time for completing the course, better job opportunities, and enhancement of knowledge, skills, and abilities play an important role among the teachers for continuing education in Higher education institutions. Out of four factors, Job opportunities is the major determinant of continuing education (.99), Knowledge, Skills, and abilities (.96), time (.95), and financial support (.89). Continuing education improves one's skills in a current job and help in gaining new skills in preparation for a career change. This study also reveals that continuing education has a positive impact on career growth and development. The impact of continuing education is more on professional growth (.92) as compared to personal growth (.76). Contınuing educatıon can help teachers to clımb the career ladder. With the help of continuing education, teachers get professional growth in terms of better job opportunities, job security, salary hike, and promotion, and personal growth helps in the development of personality, interpersonal skills, technical skills, and boosts self-confidence.

\section{DISCUSSION}

Learning is not only constrained within the boundaries of the institution, but it can also be gained from anywhere anytime by various learning modes like e-learning. Earlier smart classes, simulations learning, virtual classes were not part of the classroom but today most of the universities are well equipped with the latest technology to impart education and expect the teachers to have knowledge of the same. Continuing 
education makes the teachers equipped with the latest trend in pedagogy. When teachers discover new learning they are able to make changes to their teaching pedagogy to match the needs of the students. Higher education institutions should offer financial support to teachers through education allowance, memorandum of understanding with banks to provide education loans at low-interest rates, tie-up with government or private agencies for short term courses and workshops. Employer-sponsored continuing education will motivate the teachers to enroll for continuing education. Ravhuhali, et al., 2015 recommend that financial rewards should be given to encourage and motivate teachers for continuing professional development.

Teachers need time for completing the course and they look for support from their institutions for continuing their education. Since the teachers are busy with their academic and administrative tasks, it is difficult for them to take out enough time for attending regular classes. Teachers can be offered with the study leaves, early leaving from office, flexible timings, etc. will act as a motivator for teachers to opt for new courses for continuing education. This will act as a boon to the employers, as the teachers will become more loyal and committed to their institutions.

Teachers always seek opportunities for their knowledge, skills, and abilities. Higher education institutions can motivate teachers to participate in short term courses, seminars, workshop conferences, knowledge sharing programs, etc. for establishing professional relations outside their institutions. Higher education institutions can provide MOOC's courses, e-learning certification courses, external and internal training for increasing their knowledge.

Continuing education benefits teachers who want to improve their skills and create value in the professional field. It can help them to explore better employment opportunities or enhance their chances of getting a promotion. Higher education institutions will also reap the benefits of more skilled, satisfied, and motivated teachers, which will develop the environment of the institute. It may act as an attractive tool for drawing in new, intrinsically motivated teachers which in turn will increase admissions. Enhancing knowledge, skills, and abilities are additional important factors that motivate teachers for continuing education. Teachers can opt for multidisciplinary courses related to different functional areas viz management, psychology, etc. Such courses will not only provide vast knowledge to the working professionals regarding distinct streams but will also develop the ability among them so that they could perform different tasks simultaneously with equal efficiency.

Creating continuing education opportunities can create collaboration between the company and teachers. Corporate experts can be invited to share their knowledge and experience which will keep them updated with industrial trends. Teachers can also be sent for an industry internship program for a short duration to understand the latest development in the industry. It will help the teacher to train students better in the classroom about the industry requirement which will make a student more employable. Development 
programs like seminars, conferences, certificate programs, and workshops can be organized. Employees can be extended study leaves, employee exchanges program with other universities, sabbaticals leave, and offering distance learning education from international universities for the teachers.

\section{CONCLUSIONS}

The education sector is dynamic and rapid technological changes like digitalization or emergence of new tools call for constant re-skilling. Earlier General notion for teachers teaching in Higher education institutions was to avail the required degree, grab an opportunity in the best of the colleges, and relax for the rest of the career. With the passage of time education has evolved and today the students are exposed to varied information and are well versed with the developments around them, so the teachers imparting knowledge to them have to possess enhanced skills Teachers who do not scale up their proficiency proactively tend to suffer.

Continuing education in the workplace can be a win-win situation for both employees and employers. Continuing education boosts the confidence of the teachers and also helps in the development of the institutions and promoting quality teaching and learning (Ravhuhali, et al., 2015). Educational higher education institutions are interested in the welfare of teachers and their professional development, they offer full or partial financial aid for their continuing education. Based on the findings and recommendation it can be concluded that continuing education is beneficial for Higher education institutions as well as for teachers. continuing education has many benefits, it improves teachers' proficiency in the workplace, improves their promotion options and they learn new skills. Continuing education among teachers makes them skillful which will result in many intrinsic benefits. Highly skilled teachers bring new ideas and creativity to the job, his technical skills will be upgraded to face the rapidly changing environment. Schools and colleges that invest in the skills development of their teachers have better retention, increase teachers' morale, better job satisfaction, improve productivity and they are able to prepare future leaders.

Higher education institutions that promote continuing education see a direct financial beneficial impact on the company and at the same time, they are able to abide by the requirements framed by the government regulatory bodies. It can be seen from this research that providing financial support and time for continuing education by employers makes teachers perceive that higher education institutions see their value in the organization, in turn, effectively improves their retention.

\subsection{Practical Implication}

In the present scenario COVID19 pandemic following with lockdown ushered a challenge to the teaching fraternity to teach the students online from the home environment settings. It was expected from the teachers of humanities, management, education etc to be well versed with the technology and teach the students effectively. Undoubtedly the situation has enhanced the value of this paper as it advocates the 
importance of education and suggests measures to eliminate the barriers. This paper will equip the teachers and institutes to face unforeseen situations like lockdown in future.

In 2020 National Education policy was launched in India, instructing the higher education institutions to launch a structured development plan for the teachers so that their ability is increased. The paper will help the institutes to identify the key areas they should work on and help them to channelise their resources for the effective implementation of the policy directive. Thus this paper will serve the national goal of the country. It will provide a roadmap to all the institutes of higher education (Vinay, et al., 2020)

This research will help Higher education institutions to understand the factors which influence teachers for continuing education. Higher education institutions can provide financial support for completing the course to upgrade their knowledge and skills of their teachers. By offering education allowance, tie-up with banks for providing education Loan at low interest, tie-up with government or private agencies. Investing in teachers is one of the best ways to show that universities care about them personally. Employersponsored continuing education opportunities are the definition of a win-win situation for both teachers and universities by improving teachers' retention, resulting in reduced expenditure that would have been incurred in the selection and training of teachers. This research also showed that time constrains is one of the important factors which deprive the teachers to go for continuing education. Teachers need time for completing the course and they look for support from their universities for continuing their education. Since the Teachers are busy with their many administrative tasks, it is difficult for them to take out enough time for attending regular classes. Teachers can be offered the study leaves, early leaving from office, flexible timings, etc. will act as a motivator for teachers to opt for new courses for continuing education. This will be a boon for employers also as the teachers will become more loyal and committed to the universities.

Higher education institutions can support their teachers for continuing education by signing an agreement with International Higher education institutions, companies, and training institutes to upgrade their teacher's knowledge and skills. Higher education institutions can motivate teachers to participate in short term courses, seminars, workshop conferences, knowledge sharing programs, etc. for establishing professional relations outside the universities. As analyzed acquiring new knowledge and skills is another important factor for continuing education. Teachers can opt for multidisciplinary courses related to different functional areas viz management, psychology, etc. Such courses will not only provide vast knowledge to the working professionals regarding distinct streams but will also develop the ability among them so that they could perform different tasks simultaneously with equal efficiency. The result of the study depicts that continuing education helps in the personal and professional development of the teachers. Teacher's development leads to organization development by reducing the attrition rate and making teachers more loyal and committed to the organization. 
The paper help the service providers of higher education to customise their courses and programs in such a manner so as to support the teachers. They may offer instalments, flexible timings to complete the course as per the convenience of the learners, remove the language barriers, provide concession or discounts to the teachers thus they will be able to increase the enrolment, provide education to a larger group and at the same time increase their revenue.

Education is a building block of any economy, efficient and capable teachers in higher education will strengthen the country. The paper highlights the importance of continuing education thus prompting the government to frame policies in lieu so that it becomes a significant part of the charter of the higher education institutes.

\section{REFERENCES}

Adu, E. O., and Okeke, C. I. O. (2014). Factors Affecting Lecturers' Participation in Continuing Professional Development (CPD). Journal of Sociology and Social Anthropology, 5(3), 271-281

Alturkistani, A., Majeed, A., Car, J., Brindley, D., Wells, G., and Meinert, E. (2018). An evaluation of a Massive Open Online Course (MOOC) about data science for continuing education in healthcare.

Azra, H. A. (2020). Development of an Interactive, Patient Case-Based Training Tool for Medical Professional Continuing Education.

Bayar, A. (2013). Factors affecting teachers' participation in professional development activities in Turkey (Doctoral dissertation, University of Missouri--Columbia).

Bentler, P. M., and Bonett, D. G. (1980). Significance tests and goodness of fit in the analysis of covariance structures. Psychological bulletin, 88(3), 588.

Bindon, S. L. (2017). Professional development strategies to enhance nurses' knowledge and maintain safe practice. AORN journal, 106(2), 99-110.

Breunig, M. J., Herber, A. J., Jenkins, S. M., Newman, J. S., Beckman, T. J., Wittich, C. M., and Ratelle, J. T. (2020). Characteristics of Effective Continuing Medical Education for Physician Assistants and Nurse Practitioners in Hospital Medicine. The Journal of Physician Assistant Education, 31(1), 2-7.

Bulaeva M.N., Vaganova O.I., Gladkova M.N. (2018) Activity technologies in a professional educational institution. Baltic Humanitarian Journal, 3 (24), 167-170.

Bullock, A., Kavadella, A., Cowpe, J., Barnes, E., Quinn, B., and Murphy, D. (2020). Tackling the challenge of the impact of continuing education: an evidence synthesis charting a global, cross-professional shift away from counting hours. European Journal of Dental Education.

Bullough, R. V. (2009). The continuing education of teachers: In-service training and workshops. In International handbook of research on teachers and teaching (pp. 159-169). Springer, Boston, MA.

Byrne, B. M. (2010). Structural equation modeling with AMOS: basic concepts, applications, and programming (multivariate applications series). New York: Taylor and Francis Group, 396, 7384.

Bhaskar, P., Joshi, A., \& Dayalan, P. (2021). Investigating Inhibiting Factors Affecting MOOCS Adoption among Teachers in Higher Education Institutions of India. Business Excellence and Management, 11(2), $87-94$

Bhaskar, P., Joshi, A., \& Chopra, G. (2021). Career growth and development: the buzzword is continuing education. International Journal of Knowledge and Learning, 14(1), 39-62. 
Chaudhary, N. S., \& Bhaskar, P. (2016). Training and development and job satisfaction in education sector. Training and Development, 2(8).

Chopra, G., Bhaskar, P. Joshi, A., \& Vinay, M. (2021). Career Growth and Development: The Buzzword Is Continuing Education. International Journal of Knowledge and Learning.

Chung, C. J., Lai, C. L., and Hwang, G. J. (2019). Roles and research trends of flipped classrooms in nursing education: a review of academic publications from 2010 to 2017. Interactive Learning Environments, 1-22.

Cox, D.R. and Grus, C.L., (2019). From continuing education to continuing competence. Professional Psychology: Research and Practice, 50(2), 113.

Curran, V., Gustafson, D. L., Simmons, K., Lannon, H., Wang, C., Garmsiri, M., and Wetsch, L. (2019). Adult learners' perceptions of self-directed learning and digital technology usage in continuing professional education: An update for the digital age. Journal of Adult and Continuing Education, 25(1), 74-93.

Chaudhary, N. S., \& Bhaskar, P. (2016). Training and development and job satisfaction in education sector. Training and Development, 2(8), 42-45.

Daniels, A. S., and Walter, D. A. (2002). Current issues in continuing education for contemporary behavioral health practice. Administration and Policy in Mental Health and Mental Health Services Research, 29(4-5), 359-376.

De Souza Duarte, A., Filha, E. G. M., Silva, F. M., Varela, L. D., de Sousa Rodrigues, L., Ribeiro Filho, M. A., and de Oliveira, C. J. (2016). Consolidation of Continuing Education in Unified Health System: Facilities and Difficulties. International Archives of Medicine, 9.

Devries, S., Willett, W., and Bonow, R. O. (2019). Nutrition education in medical school, residency training, and practice. Jama, 321(14), 1351-1352.

Garuba, A. (2004). Continuing education: an essential tool for teacher empowerment in an era of universal basic education in Nigeria. International Journal of Lifelong Education, 23(2), 191-203

Grammatikopoulou, M. G., Katsouda, A., Lekka, K., Tsantekidis, K., Bouras, E., Kasapidou, E., and Chourdakis, M. (2019). Is continuing medical education sufficient? Assessing the clinical nutrition knowledge of medical doctors. Nutrition, 57, 69-73.

Grangeat, M., and Gray, P. (2007). Factors influencing teachers' professional competence development. Journal of Vocational Education and Training, 59(4), 485-501.

Griscti, O., \& Jacono, J. (2006). Effectiveness of continuing education programmes in nursing: literature review. Journal of Advanced nursing, 55(4), 449-456.

Grus, C. L., and Rozensky, R. H. (2019). Competency-based continuing education in health service psychology: Ensuring quality, recommendations for change. Professional Psychology: Research and Practice, 50(2), 106.

Gupta, K. P., \& Bhaskar, P. (2020). Inhibiting and Motivating Factors Influencing Teachers' Adoption of AlBased Teaching and Learning Solutions: Prioritization Using Analytic Hierarchy Process. Journal of Information Technology Education: Research, 19, 693-723

Gupta, K. P, Singh, S., \& Bhaskar, P. (2015). Employees' perspectives on continuing management education (CME): a study of BPO industry in Noida. Researchers World, 6(2), 141.

Gupta, K. P. \& Bhaskar, P. (2021). Teachers' intention to adopt virtual reality technology in management education. International Journal of Learning and Change.

Hair Jr, J. F., Hult, G. T. M., Ringle, C., and Sarstedt, M. (2016). A primer on partial least squares structural equation modeling (PLS-SEM). Sage publications. 
Hobjlă, A. (2014). Challenges in continuing education of primary and preschool teachers in Romania: teachers-students' parents communication. Procedia-Social and Behavioral Sciences, 142, 684-690

Hoffenson, S., Brouse, P., Gelosh, D. S., Pafford, M., Strawser, L. D., Wade, J., and Sofer, A. (2019). Grand Challenges in Systems Engineering education. In Systems Engineering in Context (pp. 47-59). Springer, Cham.

Jackson, L., Jowsey, T., and Honey, M. L. (2019). In-Service Education: Evolving Internationally to Meet Nurses' Lifelong Learning Needs. The Journal of Continuing Education in Nursing, 50(7), 313-318.

Jafri, N. A. (2009). The impact of continuing professional development on EFL faculty employed in federal universities in the United Arab Emirates.

Joshi, A., Vinay, M., \& Bhaskar, P. (2020). Impact of coronavirus pandemic on the Indian education sector: perspectives of teachers on online teaching and assessments. Interactive Technology and Smart Education.

Joshi, A., \& Bhaskar, P. Qualitative study on critical traits of teacher for effective teaching in higher education institutions.

Joshi, A., Vinay, M., \& Bhaskar, P. (2020). Online Teaching amidst COVID-19 in India: An Outlook. Asian Journal of Distance Education, 15(2), 105-111.

Kamenez, N. V., Smirnova, Z. V., Vaganova, O. I., Bystrova, N. V., and Tsarapkina, J. M. (2019). Development of Instructing Techniques in Professional Training. International Journal of Mechanical Engineering and Technology, 10(02), 899-907.

Kwakman, K. (2003). Factors affecting teachers' participation in professional learning activities. Teaching and teacher education, 19(2), 149-170.

Laal, M., Laal, A., and Aliramaei, A. (2014). Continuing education; lifelong learning. Procedia-social and behavioral sciences, 116, 4052-4056.

Lawton, S., and Wimpenny, P. (2003). Continuing professional development: a review.(art and science education). Nursing Standard, 17(24), 41-45.

Livneh, C., and Livneh, H. (1999). Continuing professional education among educators: Predictors of participation in learning activities. Adult Education Quarterly, 49(2), 91-106.

McGowan, B. S., Mandarakas, A., McGuinness, S., Olivieri, J., Ruiz-Cordell, K., Salinas, G., and Turell, W. (2020). Outcomes Standardisation Project (OSP) for Continuing Medical Education (CE/CME) Professionals: Background, Methods, and Initial Terms and Definitions. Journal of European CME, 9(1), 1717187.

McKay, L., and Sappa, V. (2019). Harnessing creativity through arts-based research to support teachers' identity development. Journal of Adult and Continuing Education, 1477971419841068.

Mohamadi, S., Borhani, F., Nikravan-Mofrad, M., Abbaszadeh, A., Monajemi, F., and Moghaddam, H. R. (2019). Assessing of the learning needs of nurses in medical and surgical and emergency wards: nursing continuing education requirements. EurAsian Journal of BioSciences, 13(2).

Myalkina E.V., Sedhyh E.P., Zhitkova V.A., Vaskina V.A., Isaykov O.I. (2018). University resource center as an element of social development of the region. Vestnik of Minin University, 6 (1).

Nagovitsyn, R. S., Bartosh, D. K., Ratsimor, A. Y., and Neverova, N. V. (2019). Modernization of Regional Continuing Pedagogical Education in the "School-College-Institute». European journal of contemporary education, 8(1), 144-156.

Neagu, G. (2014). Determinants factors of adult participation in education. Procedia-Social and Behavioral Sciences, $142,473-480$ 


\section{Bhaskar, P., \& Dayalan, P. CAREER GROWTH AND DEVELOPMENT: ROLE OF CONTINUING EDUCATION AMONG TEACHERS}

Neimeyer, G. J., Taylor, J. M., Zemansky, M. F., and Rothke, S. E. (2019). Exploring the impact of continuing education mandates: A longitudinal look. Professional Psychology: Research and Practice, 50(3), 168.

Nikonova, N. P., Vaganova, O. I., Smirnova, Z. V., Chelnokova, E. A., and Kutepov, M. M. (2019). Methodological support in partnerships with the institution of additional education and teachers. International journal of applied exercise physiology, 8(2.1), 339-346.

Oliver, P. (Ed.). (2019). Lifelong and continuing education: what is a learning society?. Routledge.

Özer, F., Doğan, N., Yalaki, Y., Irez, S., and Çakmakci, G. (2019). The ultimate beneficiaries of continuing professional development programs: Middle school students' nature of science views. Research in Science Education, 1-26.

Pérez-Foguet, A., and Lazzarini, B. (2019). Continuing professional education in engineering faculties: Transversal integration of sustainable human development in basic engineering sciences courses. Journal of cleaner production, 218, 772-781.

Portilho, E. M. L., and Medina, G. B. K. (2016). Metacognition as methodology for continuing education of teachers. Creative Education, 7(01), 1.

Priya, K., Singh, S. and Bhaskar, P., 2015. Employees' perspectives on continuing management education (CME): A study of BPO industry in Noida. Researchers World, 6(2), .141.

Ravhuhali, F., Kutame, A. P., and Mutshaeni, H. N. (2015). Teachers' perceptions of the impact of continuing professional development on promoting quality teaching and learning. International Journal of Educational Sciences, 10(1), 1-7.

Raza, N. (2010). The impact of continuing professional development on EFL teachers employed in federal universities in the United Arab Emirates. Unpublished Dissertation, The University of Exeter.

Reinstein, A., Churyk, N. T., Taylor, E. Z., and Williams, P. F. (2019). Using Accounting Department Advisory Councils and Higher Quality Continuing Education Requirements to Improve the Accounting Profession's Ethical Reasoning Skills. Advances in Accounting Education: Teaching and Curriculum Innovations (Advances in Accounting Education, Vol. 23), Emerald Publishing Limited, 177-193.

Rubin, L. J. (1969). A Study on the Continuing Education of Teachers.

Sharma Pant, S., and Poudel Panthi, L. (2018). Continuous Professional Development in Healthcare: Lifelong learning for nurses in the workplace.

Shinners, J., and Graebe, J. (2020). Continuing Education as a Core Component of Nursing Professional Development. The Journal of Continuing Education in Nursing, 51(1), 6-8.

Sockalingam, S., Tehrani, H., Lin, E., Lieff, S., Harris, I., and Soklaridis, S. (2016). Integrating quality improvement and continuing professional development: a model from the mental health care system. Academic Medicine, 91(4), 540-547.

Stolee, P., Esbaugh, J., Aylward, S., Cathers, T., Harvey, D. P., Hillier, L. M., ... and Feightner, J. W. (2005). Factors associated with the effectiveness of continuing education in long-term care. The Gerontologist, 45(3), 399-405.

Tømte, C. E. (2019). MOOCs in teacher education: institutional and pedagogical change?. European Journal of Teacher Education, 42(1), 65-81.

Tsoi, S. L. T. A., de Boer, A., Croiset, G., Koster, A. S., and Kusurkar, R. A. (2016). Factors influencing participation in continuing professional development: a focus on motivation among pharmacists. Journal of Continuing Education in the Health Professions, 36(3), 144-150.

Vaganova, O. I., Sirotyk, S. D., Popkova, A. A., Smirnova, Z. V., and Bulaeva, M. N. (2019). Additional education in higher professional educational institution. Amazonia Investiga, 8(22), 305-310. 
Bhaskar, P., \& Dayalan, P.

CAREER GROWTH AND DEVELOPMENT: ROLE OF CONTINUING EDUCATION AMONG TEACHERS

Varricchio, D. (1998). Continuing education: Expanding opportunities for officers. FBI L. Enforcement Bull., $67,10$.

Wan, S. W. Y., and Lam, P. H. C. (2010). Factors Affecting Lecturers' Participation in Continuing Professional Development (CPD): Hong Kong Primary School Lecturers' Perspectives. In AERA Annual Meeting, Colorado, USA.

Vinay, M., Bhaskar, P., \& Joshi, A. (2020, September 5). NEP 2020: Silver lining for the Indian education sector. Retrieved August 12, 2021, from Theeducationpost website: https://theeducationpost.in/nep2020-silver-lining-for-the-indian-education-sector/

Zuchowski, J. L., Hamilton, A. B., Washington, D. L., Gomez, A. G., Veet, L., and Cordasco, K. M. (2017). Drivers of continuing education learning preferences for Veterans Affairs women's health primary care providers. Journal of Continuing Education in the Health Professions, 37(3), 168-172. 